\title{
INVESTIGATION OF NEOSPORA HUGHESI ANTIBODIES BY USING ELISA IN HORSES IN NINEVEH PROVINCE
}

\author{
W.A. AL-OBAIDII and E.R. AL-KENNANY \\ Department of Microbiology, College of Veterinary Medicine, University of Mosul, Mosul, Iraq \\ Email:wasenamjad@yahoo.com
}

\section{ABSTRACT}

Received at: 17/3/2014

Accepted: 2/6/2014
The present study have been done from September 2013 to February 2014, on 90 horses of both sex and age at three different regions of Nineveh province - Iraq. Blood samples were collected from jugular vein of 90 horses, some animals appeared clinically healthy while others suffered from different clinical signs. Sera were tested for Neopora hughesi antibodies by Recombinant SAG1 Enzyme Linked Immunosorbent Assay ten horses out of $90(11.11 \%)$ reacted positively to N.hughesi antibodies. The animal aged 6-10 years recorded high prevalence and suffered from different clinical signs. The antibodies detected in male were more than that of female without any statistically significant.

Key words: Neospora hughesi, rNh ELISA, SAG1, horses, Nineveh, Iraq.

\section{INTRODUCTION}

Neospora hughesi are apicomplexan protozoa was first described in the brain and spinal cord of an adult horse in California, USA (Marsh et al., 1998) $N$.hughesi cause equine protozoal myeloencephalitis (EPM). This neurological disease has been estimated to affect about 1 in 1000 horses annually, the animal suffer from weight loss, head tilting, circling, anorexic, disorientation and symmetric muscle atrophy, the spasticity would increase when the gelding negotiated steps or changes in footing, (Nahms, 2001). The definitive host for N.hughesi is not known, the evident of N.hughesi has a wider geographic distribution since seropostive horses have been reported in the United State of America, Europe, Asia, and New Zealand (Bartova et al., 2010; Duarte et al., 2004; Pitel et al., 2001).

A treatment protocol for N.hughesi has not been described, N.hughesi can form tissue cysts and it has been suggested that because of this tissue cyst stage, the parasite would remain refractory to treatment (Carrie et al., 2007).

However, different serological methods were used to diagnose N.hughesi antibodies in horses (rNh SAG1 ELISA, IFAT, Agglutination test) with differences in sensitivity and specifity (Hoaen et al., 2005).

\section{MATERIALS and METHODS}

\section{Blood collection and preparation}

Blood samples were collected from 90 horses from both sex, different ages, from 3 localities in Nineveh province, Iraq, some animals clinically healthy and others suffer from ataxia in thoracic and pelvic limbs, ataxia appeared relatively symmetric, weight loss, symmetric muscle atrophy was noted in epaxial, gluteal, semimembranosus and semitendinosus muscles, the left pelvic limb was swollen distal to the tarsus. (Figure 1).

Blood samples $(5-10 \mathrm{ml})$ were collected from the jugular vein of each horse in vacuum tubes without anticoagulant, the blood samples were transported to the Central laboratory, College of Veterinary medicine, Mosul University, after clotting, samples were centrifuged at $3000 \mathrm{rpm}, 10$ minutes, serum was decanted and stored at $-30^{\circ} \mathrm{C}$ until tested with rELISA test for the antibodies to $N$ hughesi.

\section{Recombinant ELISA}

The rELISA was used for detection of antibodies against $N$ hughesi in serum, recombinant antigen SAG1 from the equine $N$. hughesi (rNhSAG1) was chosen for use in this test (ATTC), analysis by standard techniques (Andrea et al., 2002) the plates were coated with antigen diluted to a final concentration $1 \mathrm{ug} / \mathrm{ml}$ and later blocked with assay buffer containing 10\% dimethyle sulfoxide (DMSO) (SIGMA-ALDRICH), serum samples and peroxidase -conjugated rabbit anti-equine IgG (THERMOSCIENTIFIC) were diluted 1:100 in DMSO buffer, after incubation and washing the plate were developed, the reaction was stopped and the optical density was determined at wavelength of $450 \mathrm{~nm}$ with a reference of $650 \mathrm{~nm}$ using microplate reader to remove interpolate variation a percent positivity (PP) relative to the controls was determined for each test sample, A (PP) was used cut-off of $20 \%$, each sample, control positive and negative (UniProtKB) were run in duplicate on coated wells. 


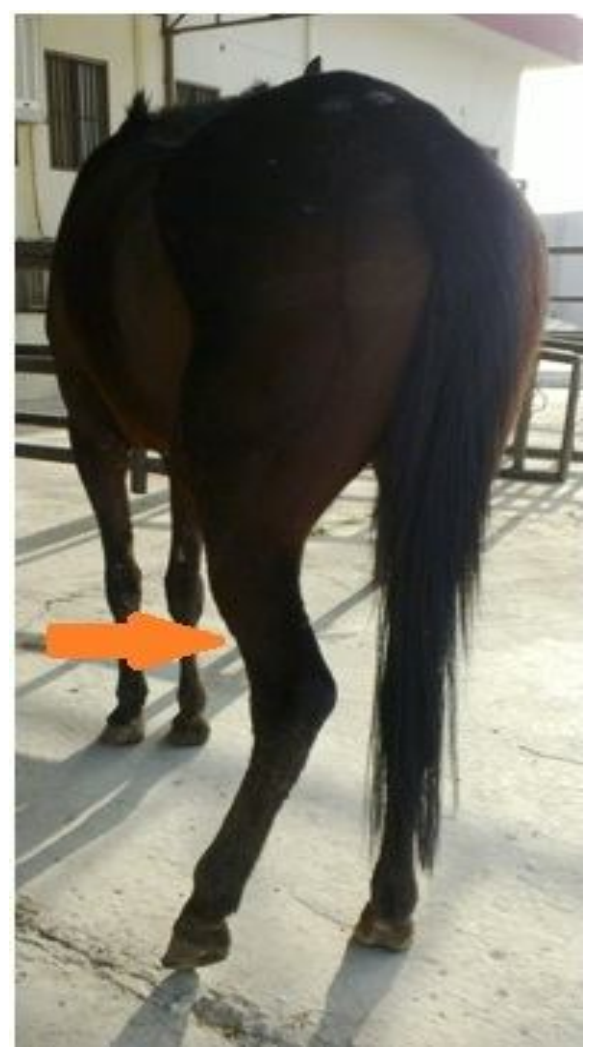

Figure 1: Horse showed ataxia and muscle atrophy of hind limb

\section{RESULTS}

Antibodies to N.hughesi were detected in 10 horses of 90 serum samples (11.11\%) based on rNhSAG1 ELISA analysis (table) the animal aged 6-10 years recorded high prevalence of antibodies, while the antibodies were not detected in animal aged 4-12 months of age (table 1).

According to the sex the male recorded high prevalence with antibodies and was not statistically significant to the percentage of infection in female.
The animal which suffer from different clinical signs showed high prevalence of antibodies than the healthy one.

The animal which suffer from muscle atrophy recorded high seroprevalence when comparing with other clinical signs which animal suffer from it (Table 2).

Table1: General characteristics of horses and seroprevalence of $N$ hughesi using rNh SAG1 ELISA.

\begin{tabular}{ccccc}
\hline Characteristics & & $\begin{array}{c}\text { No. of horses } \\
\text { tested }\end{array}$ & $\begin{array}{c}\text { N0. Seropostive } \\
\text { N.hughesi }\end{array}$ & $\begin{array}{c}\text { Percentage of infection } \\
\%\end{array}$ \\
\hline \multirow{2}{*}{ Age } & 4-12months & 8 & 0 & 0 \\
\cline { 2 - 5 } & 2-5years & 27 & 3 & 11.11 \\
\cline { 2 - 5 } & 6-10years & 43 & 6 & 13.95 \\
\cline { 2 - 5 } & 11-17years & 12 & 1 & 8.3 \\
\hline \multirow{2}{*}{ Sex } & Male & 49 & 6 & 12.24 \\
& Female & 41 & 4 & 9.76 \\
\hline
\end{tabular}


Table 2: Relationship between health status and seroprevalence of $N$ hughesi using rNh SAG1 ELISA

\begin{tabular}{lccc}
\hline Health status & No.of horses tested & $\begin{array}{c}\text { N0.Seropostive } \\
\text { N.hughesi }\end{array}$ & Percentage of infection \% \\
\hline Healthy & 81 & 3 & 3.7 \\
\hline Weight loss & 3 & 2 & 66.67 \\
\hline Ataxia & 4 & 3 & 75 \\
\hline Muscle atrophy & 2 & 2 & 100 \\
\hline
\end{tabular}

\section{DISCUSION}

This study is the first reported $N$ hughesi seroprevalence study in horses in Iraq, thus the results can be compared with other studies in different countries. In Brasil it was found that $2.6 \%$ of horses had Neospora antibodies using IFAT (Anderson et al., 2013). In Mexico, USA, 3\% of horses had $N$.hughesi antibodies, and no antibodies were detected in foal aged 4-11 months by using cELISA (Michelle et al., 2013). In California, 4\% of horses were positive to $N$.hughesi antibodies using IFAT and prevalence of antibodies against $N$.hughesi increase with age without detectable risk of trans placental transmission (Duarte et al., 2004). In Virginiana, USA $2 \%$ horses had Neospora hughesi antibodies using IFAT (Vardeleon et al., 2001). In USA antibodies of Neospora was detected in $3.4 \%$ horses by using rNhSAG1 ELISA (Hoane et al., 2004).

Sensitivity and specificity exhibited by the rNhSAG1 ELISA suggest that it has a potential use for serodiagnosis of N.hughesi infection in equine when compared with other serological test (Hoane et al., 2005).

The animal which suffer from different clinical signs and suffer from muscle atrophy records high prevalence, this result consistent to the researchers (Carrie et al., 2007) which reported that the N.hughesi in 3 horses which examined clinically and serology, the clinical signs in the 3 horses suffer from ataxia, loss of body weight, muscle atrophy, head tilting, and these researchers give rise to infection with N.hughesi.

In conclusion, in this study we found that the $N$.hughesi antibodies have relatively high prevalence when compared this prevalence with other sero prevalence studies in other countries, because no case to use anti-protozoal drugs used in treatment of the horses furthermore no vaccine used.

\section{ACKNOWGMENT}

We are grateful to the Dean of the College Veterinary Medicine, University of Mosul and staff of Central
Laboratory, Also, the authors would like to thank all horse owners for their consent to collect blood samples and the staff of farms.

\section{REFERNCES}

Anderson, B.M.; Márcio, O.S.; Juliana, A.F.; Achilles, V.N.; Antonio, P.S.; Amélia, A.S.; Joandes, H.F. and Silvério, B. (2013): Neospora hughesi. antibodies in horses from two geographical regions of the state of Santa Catarina, Brazil, Rev. Bras. Parasitol. Vet. 22 (4): 99-102.

Andrea, E.P.; Patrica, A.C.; Wilson, W.D.; Lisa, V.J.; Karen, S.W.; Ian, A.G.; Barbara, M.D.; Antoinette, E.M.; Byron, L.B.; Gregory, L.F. and Bradd, C.B. (2002): Qualitative evaluation of selective tests for detection of Neospora hughesi antibodies in serum and cerebrospinal fluid of experimentally infected horses. J. Parasitol. 88(6): 1239-1246.

Bartova, E.; Sediak, K.; Syrova, M. and Literak, I. (2010): Neospora spp and Toxoplasma gondii antibodies in horses in the Czech Republic. Parasitol. Res. 107: 783-785.

Carrie, J.F.; Monica, A and Nicola, P. (2007): Quine protozoal Myeloencepalitis associated with neosporosis in 3 horses. J. Vet. Intern. Med. 21: 1405-1408.

Durate, P.C.; Conrad, P.A.; Wilson, W.D.; Ferraro, G.L.; Packham, A.E.; Bower-Lepore, J.; Carpenter, T.E. and Gardener, I.A. (2004): Risk of postnatal exposure to Sarcocyst neurona and Neoposra hughesi in horses. American Journal of Veterinary Research. 65(8):1047-1052.

Hoane, J.S.; Morrow, J.K.; Saville, W.J. and Howe, D.K. (2004): Neospora hughesi Seroprevalence in Equids, J. PARASITOLOGY; 92 (1): 73-74.

Hoaen, J.S.; Yeargen, M.R.; Stamper, S.; Saville, W.J.; Morrow, J.K.; Lindasy, D.S. and Howe, D.K. (2005): Recombinant NhSAG1 ELISA: a sensitive and specific assay for detection antibodies against Neospora hughesi in equine serum. J. Parasitol. 91(2): 446-452.

Marsh, A.E.; Barr, B.C.; Packham, A.E. and Conrad, P.A. (1998): Description of anew Neospora 
species (Protozoa: Apicomplexa:

Sarcocysridae). Parasitoloigy, 84: 983-991.

Michelle, Y.; Alvardo-Esqivel, C.; Dubey, J.P. and Howe, D.K. (2013): Prevalence of antibodies to Sarcocyst neurona and Neospora hughesi in horses in Mexico. Parasite. 20(29): 10-13.

Nahms, R. (2001): $\quad$ Equine protozoal Myeloenceplalitis (EPM) in the US., USDA. APHIS, VS, Editors. Fort Collis, Co:Centers for Epidemiology and Animal Health. Parasitol, 1 (2): 273-282.
Pitel, P.H.; Pronost, S.; Romand, S.; Thulliez, P.; Fortier, G. and Balet, J. (2001): Prevalence of antibodies to Neospora in horses in France. Eq. Vet. J. 33: 205-207.

Vardeleon, D.; Marsh, A.E.; Thome, J.G.; Loch, W.; Young, R. and Johnson, P. (2001): Prevalence of Neospora hughesi and Sarcocystis neurona antibodies in horses from various geographical locations.Vet. Parasitol, 26(3): 102-108.

\section{التقصي عن اضداد البوغة الخيلية باستخدام المقايسة المناعية المرتبطة بالانزيم في خيول محافظة نينوى \\ وسن امجد العبياي ، انتصار رحيم الكناني \\ Email:wasenamjad@yahoo.com}

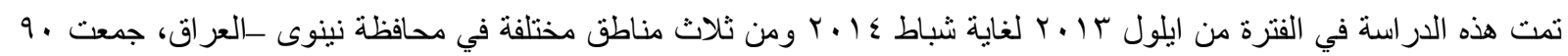

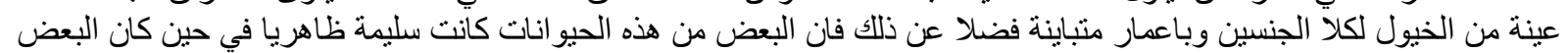

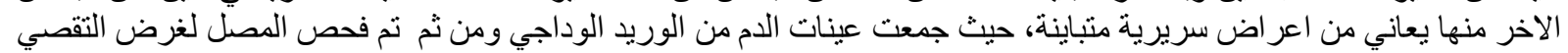

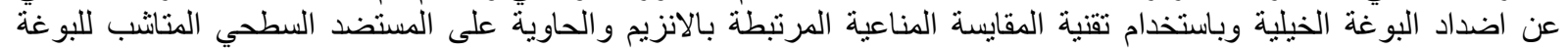

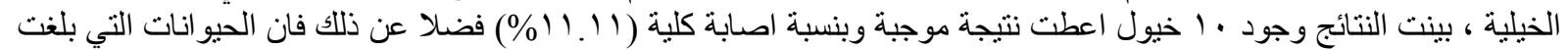

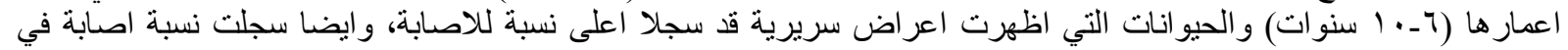

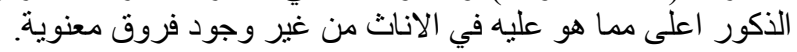

الكلمات المفتاحية: البوغة الخيلية ، تقتية المقايسة المناعية المرتبطة بالانزيم الحاوية على المستضد السطحي المتاثب للبوغة الخيلية

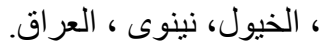

